\title{
RESULTS OF QUALITY-CONTROL SAMPLING OF WATER, BED SEDIMENT, AND TISSUE IN THE WESTERN LAKE MICHIGAN DRAINAGES STUDY UNIT OF THE NATIONAL WATER- QUALITY ASSESSMENT PROGRAM
}

\section{By Sharon A. Fitzgerald}

U.S. GEOLOGICAL SURVEY

Water-Resources Investigations Report 97-4148

NATIONAL WATER-QUALITY ASSESSMENT PROGRAM

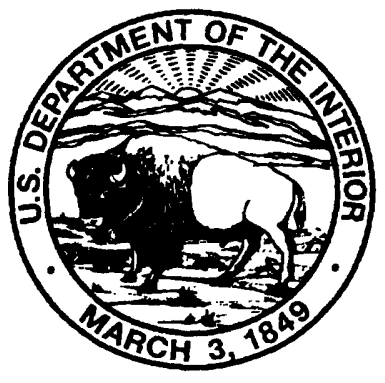

Middleton, Wisconsin 1997 


\title{
U.S. DEPARTMENT OF THE INTERIOR BRUCE BABBITT, Secretary
}

\author{
U.S. GEOLOGICAL SURVEY \\ Gordon P. Eaton, Director
}

District Chief

U.S. Geological Survey

8505 Research Way

Middleton, WI 53562
U.S. Geological Survey

Branch of Information Services

Box 25286

Denver, CO 80225-0286 


\section{FOREWORD}

The mission of the U.S. Geological Survey (USGS) is to assess the quantity and quality of the earth resources of the Nation and to provide information that will assist resource managers and policymakers at Federal, State, and local levels in making sound decisions. Assessment of water-quality conditions and trends is an important part of this overall mission.

One of the greatest challenges faced by waterresources scientists is acquiring reliable information that will guide the use and protection of the Nation's water resources. That challenge is being addressed by Federal, State, interstate, and local water-resource agencies and by many academic institutions. These organizations are collecting water-quality data for a host of purposes that include: compliance with permits and water-supply standards; development of remediation plans for specific contamination problems; operational decisions on industrial, wastewater, or watersupply facilities; and research on factors that affect water quality. An additional need for water-quality information is to provide a basis on which regionaland national-level policy decisions can be based. Wise decisions must be based on sound information. As a society we need to know whether certain types of water-quality problems are isolated or ubiquitous, whether there are significant differences in conditions among regions, whether the conditions are changing over time, and why these conditions change from place to place and over time. The information can be used to help determine the efficacy of existing waterquality policies and to help analysts determine the need for and likely consequences of new policies.

To address these needs, the U.S. Congress appropriated funds in 1986 for the USGS to begin a pilot program in seven project areas to develop and refine the National Water-Quality Assessment (NAWQA) Program. In 1991, the USGS began full implementation of the program. The NAWQA Program builds upon an existing base of water-quality studies of the USGS, as well as those of other Federal, State, and local agencies. The objectives of the NAWQA Program are to:

- Describe current water-quality conditions for a large part of the Nation's freshwater streams, rivers, and aquifers.
- Describe how water quality is changing over time.

- Improve understanding of the primary natural and human factors that affect water-quality conditions.

This information will help support the development and evaluation of management, regulatory, and monitoring decisions by other Federal, State, and local agencies to protect, use, and enhance water resources.

The goals of the NAWQA Program are being achieved through ongoing and proposed investigations of 60 of the Nation's most important river basins and aquifer systems, which are referred to as study units. These study units are distributed throughout the Nation and cover a diversity of hydrogeologic settings. More than two-thirds of the Nation's freshwater use occurs within the 60 study units and more than twothirds of the people served by public water-supply systems live within their boundaries.

National synthesis of data analysis, based on aggregation of comparable information obtained from the study units, is a major component of the program. This effort focuses on selected water-quality topics using nationally consistent information. Comparative studies will explain differences and similarities in observed water-quality conditions among study areas and will identify changes and trends and their causes. The first topics addressed by the national synthesis are pesticides, nutrients, volatile organic compounds, and aquatic biology. Discussions on these and other waterquality topics will be published in periodic summaries of the quality of the Nation's ground and surface water as the information becomes available.

This report is an element of the comprehensive body of information developed as part of the NAWQA Program. The program depends heavily on the advice, cooperation, and information from many Federal, State, interstate, Tribal, and local agencies and the public. The assistance and suggestions of all are greatly appreciated.

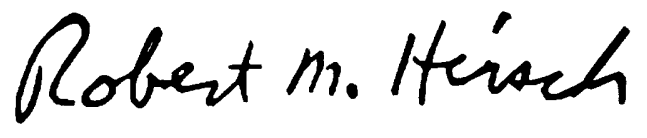

Robert M. Hirsch Chief Hydrologist 



\section{CONTENTS}

Abstract

Introduction

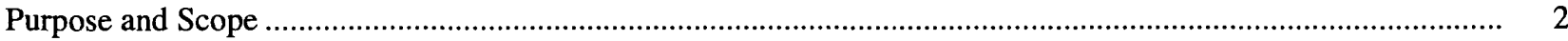

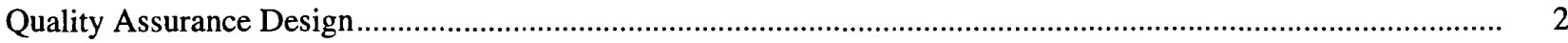

Types and Objectives of Quality-Control Sampling .......................................................................................

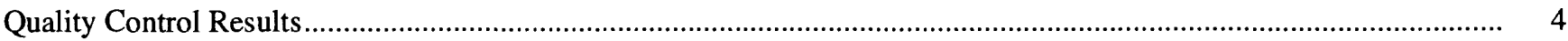

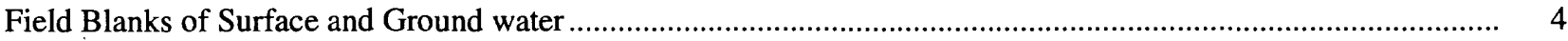

Field Replicates of Surface and Ground Water .............................................................................................

Field Replicates and Splits of Bed Sediment .............................................................................................

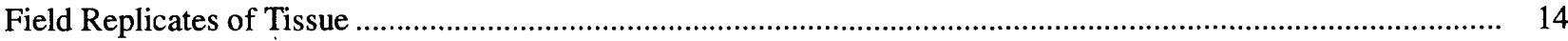

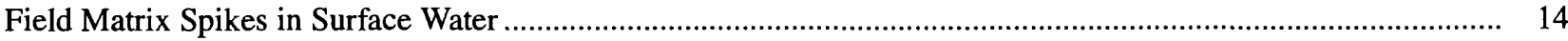

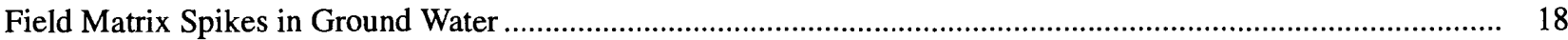

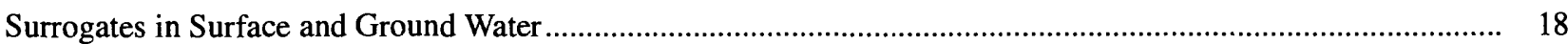

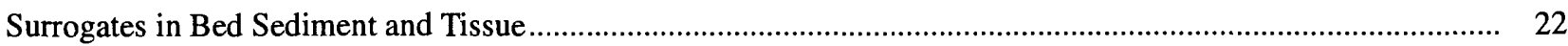

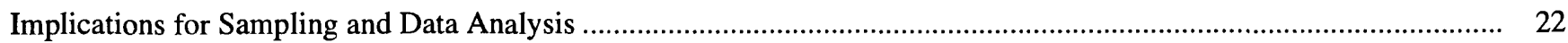

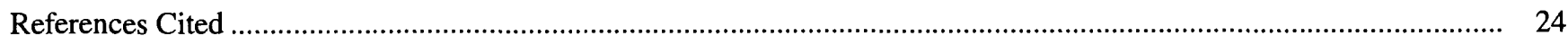

\section{TABLES}

1. Detections of target analytes in field blank samples ....................................................................................

2. Precision of field replicate samples of surface and ground water .............................................................

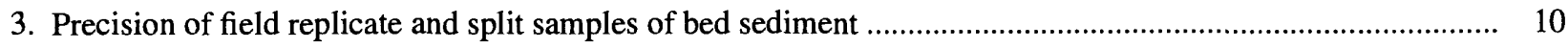

4. Precision of field replicate samples of tissue .......................................................................................... 15

5. Precision and recovery of field matrix spikes in surface water samples...................................................... 16

6. Precision and recovery of field matrix spikes in ground water samples ................................................ 19

7. Recovery of trace organic surrogates in surface and ground water samples .............................................. 22

8. Recovery of trace organic surrogates in bed sediment and tissue samples................................................... 22 
CONVERSION FACTORS AND ABBREVIATED WATER-QUALITY UNITS

\begin{tabular}{rll}
\hline Multiply & \multicolumn{1}{c}{ By } & \multicolumn{1}{c}{ To obtain } \\
\hline kilogram $(\mathrm{kg})$ & $3.52 \times 10^{-5}$ & ounce, avoirdupois \\
gram $(\mathrm{g})$ & $3.52 \times 10^{-2}$ & ounce \\
milligram $(\mathrm{mg})$ & $3.52 \times 10^{1}$ & ounce \\
microgram $(\mu \mathrm{g})$ & $3.52 \times 10^{4}$ & ounce \\
$\operatorname{liter}(\mathrm{L})$ & $2.64 \times 10^{-1}$ & gallon \\
millimeter $(\mathrm{mm})$ & $3.94 \times 10^{-2}$ & inch \\
micrometer $(\mu \mathrm{m})$ & $3.94 \times 10^{-5}$ & inch \\
\hline
\end{tabular}

Abbreviated water-quality units: Chemical concentrations are given in metric units. Chemical concentration for solutions is given in milligrams per liter $\left(\mathrm{mg} \cdot \mathrm{L}^{-1}\right.$ or $\mathrm{mg} / \mathrm{L}$ ) or micrograms per liter $\left(\mu \mathrm{g} \cdot \mathrm{L}^{-1}\right.$ or $\left.\mu \mathrm{g} / \mathrm{L}\right)$ for the weight of solute (milligrams or micrograms) per unit volume (liter) of water. For concentrations less than $7,000 \mathrm{mg} \cdot \mathrm{L}^{-1}$, the numerical value expressed in units of milligrams per liter is the same as that for concentration.expressed in parts per million. Chemical concentrations for solids is given in weight percent (Wt\%), micrograms per gram $\left(\mu \mathrm{g} \cdot \mathrm{g}^{-1}\right.$ or $\mu \mathrm{g} / \mathrm{g}$ ), or micrograms per kilogram $\left(\mu \mathrm{g} \cdot \mathrm{kg}^{-1}\right.$ or $\mu \mathrm{g} /$ $\mathrm{kg}$ ) for the mass of constituent (grams x 100, micrograms or kilograms) per unit mass (gram or kilogram) of dry bed sediment or (wet or dry) biological tissue.

\section{MISCELLANEOUS ABBREVIATIONS}

$\begin{array}{ll}\text { DOC } & \text { Dissolved organic carbon } \\ \text { MRL } & \text { Laboratory Method Reporting Limit } \\ \text { NAWQA } & \text { National Water-Quality Assessment } \\ \text { as N } & \text { as quantified as measured nitrogen } \\ \text { as P } & \text { as quantified as measured phosphorus } \\ \text { PAH } & \text { Polyaromatic hydrocarbon } \\ \text { PCB } & \text { Polychlorinated biphenyl } \\ \text { SOC } & \text { Suspended organic carbon } \\ \text { USGS } & \text { U.S. Geological Survey } \\ \text { VOCs } & \text { Volatile organic compounds }\end{array}$




\section{ACKNOWLEDGMENTS}

\section{Technical Support}

Faith A. Fitzpatrick, Hydrologist, U.S. Geological Survey, Middleton, Wis.

Kevin D. Richards, Physical Scientist, U.S. Geological Survey, Middleton, Wis.

Dale M. Robertson, Research Hydrologist, U.S. Geological Survey, Middleton, Wis.

David A. Saad, Hydrologist, U.S. Geological Survey, Middleton, Wis.

Barbara C. Scudder, Hydrologist, U.S. Geological Survey, Middleton, Wis.

James G. Setmire, Hydrologist, U.S. Geological Survey, Sacramento, Cal.

Jana S. Stewart, Geographer, U.S. Geological Survey, Middleton, Wis.

Daniel J. Sullivan, Hydrologist, U.S. Geological Survey, Middleton, Wis.

\section{Technical Reviewers}

William T. Foreman, Research Chemist, U.S. Geological Survey, Denver, Col.

Edward T. Furlong, Research Chemist, U.S. Geological Survey, Denver, Col.

Jeffrey D. Martin, Hydrologist, U.S. Geological Survey, Indianapolis, Ind.

Charles A. Peters, Chief Supervisory Hydrologist, U.S. Geological Survey, Middleton, Wis.

Mark W. Sandstrom, Methods Research \& Development Program Chief, U.S. Geological Survey, Denver, Col.

Michael P. Schroeder, Supervisory Chemist, U.S. Geological Survey, Denver, Col.

Daniel J. Sullivan, Hydrologist, U.S. Geological Survey, Middleton, Wis.

\section{Editorial}

Elizabeth A. Ciganovich, Technical Publications Editor, U.S. Geological Survey, Middleton, Wis. Heather E. Whitman, Physical Science Aid, U.S. Geological Survey, Middleton, Wis.

\section{Approving Officials}

Michael C. Yurewicz, Assistant Regional Hydrologist - NAWQA, U.S. Geological Survey, Reston, Virg.

Chester Zenone, Reports Improvement Advisor, U.S. Geological Survey, Reston, Virg. 


\title{
Results of Quality-Control Sampling of Water, Bed Sediment, and Tissue in the Western Lake Michigan Drainages Study Unit of the National Water-Quality Assessment Program
}

\author{
By Sharon A. Fitzgerald
}

\section{Abstract}

This report contains the quality control results of the Western Lake Michigan Drainages study unit of the National Water Quality Assessment Program. Quality control samples were collected in the same manner and contemporaneously with environmental samples during the first highintensity study phase in the unit (1992 through 1995) and amounted to approximately 15 percent of all samples collected. The accuracy and precision of hundreds of chemical analyses of surface and ground-water, bed sediment, and tissue was determined through the collection and analysis of field blanks, field replicates and splits, matrix spikes, and surrogates. Despite the several detections of analytes in the field blanks, the concentrations of most constituents in the environmental samples will likely be an order of magnitude or higher than those in the blanks. However, frequent detections, and high concentrations, of dissolved organic carbon (DOC) in several surface and ground-water blanks are probably significant with respect to commonly measured environmental concentrations, and the environmental data will have to be qualified accordingly. The precision of sampling of water on a percent basis, as determined from replicates and splits, was generally proportional to the concentration of the constituents, with constituents present in relatively high concentrations generally having less sampling variability than those with relatively low concen- trations. In general, analytes with relatively high variability between replicates were present at concentrations near the reporting limit or were associated with relatively small absolute concentration differences, or both. Precision of replicates compared to that for splits in bed sediment samples was similar, thus eliminating sampling as a major source of variability in analyte concentrations. In the case the phthalates in bed sediment, contamination in either the field or laboratory could have caused the relatively large variability between replicate samples and between split samples. Variability of analyte concentrations in tissue samples was relatively low, being 29 percent or less for all constituents. Recoveries of most laboratory schedule $2001 / 2010$ pesticide spike compounds in surfacewater samples were reasonably good. Low intrinsic method recovery resulted in relatively low recovery for $p, p^{\prime}$-DDE, metribuzin, and propargite. In the case of propargite, decomposition with the environmental sample matrices was also indicated. Recoveries of two compounds, cyanazine and thiobencarb, might have been biased high due to interferences. The one laboratory schedule 2050/2051 field matrix pesticide spike indicated numerous operational problems with this method that biased recoveries either low or high. Recoveries of pesticides from both pesticide schedules in field spikes of ground-water samples generally were similar to those of field matrix spikes of surface-water samples. High maximum recoveries were noted for tebuthiuron, disulfoton, DCPA, and 
permethrin, which indicates the possible presence of interferents in the matrices for these compounds. Problems in the recoveries of pesticides on schedule 2050/2051 from ground-water samples generally were the same as those for surfacewater samples. Recoveries of VOCs in field matrix spikes were reasonable when consideration was given for the use of the micropipettor that delivered only about 80 percent on average of the nominal mass of spiked analytes. Finally, the recoveries of most surrogate compounds in surface and ground-water samples were reasonable. Problems in sample handling (for example, spillage) were likely not the cause of any of the low recoveries of spiked compounds.

\section{INTRODUCTION}

In 1991, the U.S. Geological Survey (USGS) began full-scale implementation of the National Water Quality Assessment (NAWQA) Program. The main goal of the NAWQA Program is to describe the status and trends in the quality of the Nation's surface-water and ground-water resources (Gilliom and others, 1994). The Western Lake Michigan Drainages study unit, one of 20 started in 1991, is located in the eastern third of Wisconsin and includes part of the Upper Peninsula of Michigan. The quality of surface and groundwater throughout the study unit was assessed through collection of water, bed sediment, and tissue samples and the analysis of those samples for hundreds of chemical constituents. A quality-assurance plan specifying types, numbers and timing of quality-control samples was developed to determine the accuracy and precision of these environmental data collected in the Western Lake Michigan Drainages study unit.

\section{Purpose and Scope}

The purpose of this report is to describe the results of the quality-control program in the Western Lake Michigan Drainages study unit for the primary studies conducted from 1992 through 1995. Sample matrices included surface water (from basic fixed sites and intensive fixed sites), ground water (from studyunit surveys, land-use surveys, and a flow-path study), and bed sediment and tissue (from the occurrence and distribution study). All nonestimated (no analytical problems noted) quality-control data for surface and ground-water, bed sediment, and tissue were evaluated. Other quality-control data that are specific to laboratory procedures are available from the U. S. Geological Survey's National Water Quality Laboratory (NWQL) in Arvada, Colorado.

\section{Quality Assurance Design}

Quality assurance (QA) refers to the procedures used to ensure the accuracy and precision of an analysis. Quality control (QC) is the collective analysis of the results of the quality-assurance procedures. The design closely follows the NAWQA protocols for the collection of water-quality data for surface water (Shelton, 1994), ground water (Koterba and others, 1995), tissue (Crawford and Luoma, 1993), and bed sediment (Shelton and Capel, 1994). References for all analytical methods are available on the NWQL World Wide Web Site (http://wwwnwql.usgs.gov/USGS/ref_list.html). The target analyte schedules also are on the Web (http:/ /wwwdwimdn.er.usgs.gov/nawqa/schedules.html). As regards the two pesticide schedules, triazines, organochlorines, organophosphates, chlorinated amides, and carbamates are the most common compound types in schedule 2001/2010, and carbamates, chlorophenoxy acids, phenyl ureas, and various pyridines are the most common compound types in schedule 2050/2051.

In general, about 15 percent of all samples collected were quality-control samples of some type. Blanks were analyzed for all analytes in surface and ground-water. Replicates were collected and analyzed for all analytes in all types of media. Field matrix spikes were analyzed with all trace organic analyses in water. Surrogates were added to samples of all media analyzed for trace organic compounds. For surface water, all of the field matrix spikes were prepared at one station during the first 2 field years. Blanks and replicates were collected intermittently throughout the sampling period at all study sites. For ground-water samples, a field blank was analyzed at the beginning of each field season. Other quality-control samples for ground water were collected and analyzed randomly throughout the sampling period. For bed sediment and tissue samples, quality-control samples, either replicates, splits, or both, were collected and analyzed intermittently among sites that afforded ample sediment or tissue. The tissue samples were either caddis fly (Hydropsyche spp., Ceratopsyche spp., or Cheumatopsyche spp.) or stone fly (Acroneuria sp.), which were 
analyzed for inorganic constituents, and white sucker (Catostomas commersoni), which was analyzed for trace organic compounds. In the case of the caddis flies, some samples consisted of mixtures of Hydropsyche spp. and Ceratopsyche spp..

\section{Types and Objectives of Quality-Control Sampling}

Field blanks were analyzed to assess contamination of surface and ground water environmental samples by the field environment, sampling equipment, the sample bottles, or any other source of contamination during transportation of field equipment to the field site, shipment of the sample to the laboratory, or at the laboratory during analysis. The water used for blanks was certified to contain concentrations of the target analytes that were below the laboratory reporting limits. However, occasional detections of target analytes in the blanks, mostly volatile organic compounds (VOCs) have been noted (U.S. Geological Survey National Water Quality Laboratory Technical Memorandum 9201 ). This was considered in the interpretation of blank samples analyzed for VOCs. Commercially available high-performance liquid chromatography (HPLC)grade water, procured from and quality-controlled at NWQL, was used in the field blanks analyzed for dissolved organic carbon (DOC) and trace organic constituents; distilled, demineralized water generated at the USGS Ocala Laboratory (Ocala, Florida) was used in the blanks analyzed for inorganic constituents. Blank water for VOCs was HPLC-grade water that was determined to have no target VOCs above the reporting limits. The purpose of the field blanks was to estimate the frequency and magnitude of contamination in environmental samples from any source at levels that could affect results of the analyses of the environmental samples. Analyte detections coded to indicate that the value could only be estimated were not considered in this analysis. Problematic analytical results for quality-control samples cannot be used to establish the accuracy and precision of the entire data set, although some marginal information could possibly be gleaned from the analyses (for example, calculating a minimum variability for a particular analyte from replicate samples when one replicate had a reported concentration less than the detection limit). However, certain environmental samples with estimated concentrations of analytes could possibly be interpreted within the established accuracy and precision determined from non-problematic qual- ity-control samples. An example of this would be the coding of all detections of a particular analyte as "qualitative only" based on previously established quality control.

Trip blanks are samples of water shipped from the NWQL to the District office where they are stored prior to being taken out in the field during sampling, and subsequently shipped back, unopened, to the NWQL with the environmental samples for VOC analysis. Trip blanks are designed to isolate contamination occurring during the shipment of VOC samples to the laboratory, but they also would indicate contamination prior to sample shipment that might have occurred during shipment of the blank to the District or during its storage there. Estimated concentrations for constituents in trip blanks were not considered in this analysis for the reason stated above for field blanks.

Field replicates (duplicates or triplicates) consisted of two or three separately collected samples of all media (surface water, ground water, bed sediment, and tissue). Replicates were used to determine the variability of the overall protocol, including all steps from the actual sampling procedure to analysis of the samples. Because of this, the replicate samples reflect the maximum variability in analyzed concentrations in that they "integrate" all sources of variability. Replicates were collected either sequentially, in the case of some surface-water samples and all ground-water, bed sediment and tissue samples, or concurrently, in the case of DOC in surface water. Field splits, which are two aliquots taken from a single composite sample, were analyzed to assess the variability of handling, shipment, and analysis apart from the actual field sampling procedure. Field splits were done in some surface-water and bed-sediment samples. In the case of surface-water samples analyzed for constituents other than DOC, the records are not available to distinguish with confidence between sequential replicates and splits. Thus, all surface-water samples are referred to as simply "replicates". Finally, only replicate and split samples that had analyte detections for both samples in the set were considered in the data analysis. In general, constituents detected in only one of a pair of replicate samples or split samples were present at concentrations near the reporting limit, an outcome that would be expected to occur often by chance and is of minor significance. Although it is possible to calculate a minimum precision from these data (replicate pairs with only one detection), it was felt that enough other replicate sets were available to determine variability with much more 
confidence. Also, as with the blanks, estimated concentrations of analytes were not considered in this analysis for the above stated reason.

Field matrix spikes are defined here as spikes that were added to some environmental samples of surface and ground water and were analyzed to assess the recovery efficiency of some or most of the target analytes on the pesticide and VOC schedules. Analyte recovery can be affected by certain matrix characteristics that can bias recovery high, as in the case of interferences, or low, as in the case of intrinsic method performance (for example, poor retention on solid phase extraction columns, instability in solution, or irreversible sorption on containers), analyte decomposition, sample loss during analysis, or any combination of these factors. Interferences are elements or compounds that "co-elute" with target analytes during analysis and, thus, erroneously enhance the apparent recovery efficiency of the spiked compound. Interferences can be detected by comparison with the unspiked environmental samples. Analyte decomposition, which can occur by reaction of the analyte with other chemical constituents in the environmental samples, results in an erroneously low analyte recovery. Decomposition can be inferred from analyte recovery below that expected from the average intrinsic method performance. Field matrix spikes were always prepared in duplicate and were always accompanied by an unspiked sample, which was needed to correct calculated recoveries for environmental concentrations of target compounds. The recovery efficiency that was calculated reflects all sources of bias associated with sampling, handling, spiking, shipment, and analysis and, as such, was the maximum bias associated with the entire procedure. Estimated concentrations of analytes were not considered in this analysis for reasons stated above.

Surrogates are compounds added to samples that are similar in physiochemical properties to at least some of the target analytes but that are not expected to be found in the samples. These compounds were used to assess unexpected (as in a spilled sample) analyte loss during the entire procedure from extraction to analysis. They are selected on the basis that they are expected to behave similarly in the analytical procedure to the targets and are typically fluorinated, brominated, or isotopically labeled. Between one and four surrogates are added to a sample, depending on the particular analysis. Surrogates for pesticides in surfacewater samples were generally added in the field prior to field extraction, whereas surrogates for VOCs in ground-water samples and surrogates for trace organic compounds in bed sediment and tissue samples were always added in the laboratory immediately before extraction. Surrogates can also be used to investigate matrix effects on analyte recovery when compared to recovery in reagent spikes. Surrogates were added to all environmental samples, spiked samples, and blanks that were analyzed for pesticides and VOCs in water and trace organics in bed sediment and tissue. Estimated concentrations of analytes were not considered in this analysis for reasons stated above.

\section{QUALITY CONTROL RESULTS}

This report contains a summary of the quality control data for the first high intensity sampling phase (1992-1995) in the Western Lake Michigan Drainages NAWQA study unit. All quality control data are available on the Western Lake Michigan Drainages NAWQA Web site (http://wwwdwimdn.er.usgs.gov/ nawqa/index.html).

\section{Field Blanks of Surface and Ground Water}

For surface water, the most frequently detected constituents in field blanks were alkalinity as $\mathrm{CaCO}_{3}$ (94 percent), DOC (83 percent), calcium ( 88 percent), silica (76 percent), magnesium and ammonium-Nitrogen (both 53 percent), and atrazine (50 percent)(table 1). Of these, the highest concentration detected relative to the reporting limit was that for silica, which was 660 -fold higher. The median concentrations for all constituents were all within a factor of 10 above the method reporting limit, but most detections were within a factor of two or three above the method reporting limit. Detections of alkalinity as $\mathrm{CaCO}_{3}$ and ammonium-Nitrogen in the blank water were not unexpected and resulted from carbon dioxide and ammonia dissolution, respectively. In the case of ammonia, an additional source appears to be the NWQL, because for water year 1994 and thereafter, about 50 percent of laboratory blanks had detectable levels of ammoniumNitrogen (P.F. Rogerson, U.S. Geological Survey, written commun., 1997). The silica detections probably were associated with short-term sample storage in precleaned glass bottles. Detections of calcium, magnesium, DOC, and atrazine, probably resulted from inadequate cleaning of the sample splitter.or filtration 
Table 1. Detections of target analytes in field blank samples

[All data is given in concentration units. N, number of blanks; $D$, detections, in percent; MRL, Method Reporting Limit; min, minimum observed value or concentration; max, maximum observed value or concentration; med, median observed value or concentration; $\mathrm{mg} / \mathrm{L}$, milligrams per liter; $\mu \mathrm{g} / \mathrm{L}$, micrograms per liter; $\mathrm{CaCO}_{3}$, calcium carbonate; DOC, dissolved organic carbon; VOCs, volatile organic compounds]

\begin{tabular}{llllllll}
\hline \multirow{2}{*}{ Constituent or Compound } & N & & \multicolumn{4}{c}{ Concentration } \\
\cline { 3 - 6 } & & & MRL & $\min$ & $\max$ & $\operatorname{med}$ \\
\hline
\end{tabular}

Major Ions:

calcium $(\mathrm{mg} / \mathrm{L})$
magnesium $(\mathrm{mg} / \mathrm{L})$
sodium $(\mathrm{mg} / \mathrm{L})$
chloride $(\mathrm{mg} / \mathrm{L})$
sulfate $(\mathrm{mg} / \mathrm{L})$
fluoride $(\mathrm{mg} / \mathrm{L})$
silica $(\mathrm{mg} / \mathrm{L})$
iron $(\mu \mathrm{g} / \mathrm{L})$
alkalinity $\left(\right.$ as $\left.\mathrm{CaCO}_{3}\right)$
$\quad(\mathrm{mg} / \mathrm{L})$

Nutrients $(m g / L)$ :

ammonium-nitrogen

nitrite-nitrogen

phosphorus, total

phosphorus, dissolved

DOCs $(m g / L)$ :

Pesticides - 2001/2010 ( $\mathrm{gg} / \mathrm{L})$ :

malathion

atrazine

Major Ions:

calcium (mg/L)

magnesium (mg/L)

sodium (mg/L)

chloride $(\mathrm{mg} / \mathrm{L})$

sulfate $(\mathrm{mg} / \mathrm{L})$

fluoride $(\mathrm{mg} / \mathrm{L})$

\section{Surface Water}

17

$\begin{array}{lllll}88 & 0.02 & 0.02 & 0.66 & 0.04 \\ 53 & 0.01 & 0.01 & 0.05 & 0.03 \\ 35 & 0.20 & 0.6 & 1.3 & 0.75 \\ 24 & 0.1 & 0.1 & 0.5 & 0.30 \\ 24 & 0.10 & 0.2 & 0.2 & 0.20 \\ 12 & 0.10 & 0.1 & 0.1 & 0.10 \\ 76 & 0.01 & 0.02 & 6.6 & 0.08 \\ 24 & 3.0 & 6.0 & 15 & 7.5 \\ 94 & 1.0 & 1.1 & 6.0 & 1.8\end{array}$

17

$\begin{array}{llllll} & 53 & 0.02 & 0.02 & 0.05 & 0.02 \\ & 24 & 0.01 & 0.01 & 0.02 & 0.02 \\ & 35 & 0.01 & 0.01 & 0.02 & 0.02 \\ & 29 & 0.01 & 0.01 & 0.02 & 0.02 \\ 4 & 83 & 0.01 & 0.2 & 2.0 & 0.25 \\ & & & & & \\ & & & & & 0.007 \\ & 25 & 0.01 & 0.007 & 0.007 & 0.004\end{array}$

\section{Ground Water}

9

$\begin{array}{lllll}89 & 0.02 & 0.03 & 0.68 & 0.14 \\ 44 & 0.01 & 0.01 & 0.2 & 0.03 \\ 33 & 0.20 & 0.6 & 0.9 & 0.8 \\ 22 & 0.1 & 0.1 & 0.8 & 0.45 \\ 22 & 0.10 & 0.1 & 0.2 & 0.15 \\ & 0.10 & 0.1 & 0.1 & 0.1\end{array}$


Table 1. Detections of target analytes in field blank samples-Continued

\begin{tabular}{|c|c|c|c|c|c|c|}
\hline \multirow{2}{*}{ Constituent or Compound } & \multirow{2}{*}{$\mathbf{N}$} & \multirow{2}{*}{ D } & \multicolumn{4}{|c|}{ Concentration } \\
\hline & & & MRL & $\min$ & $\max$ & med \\
\hline silica $(\mathrm{mg} / \mathrm{L})$ & & 89 & 0.01 & 0.03 & 4.5 & 0.28 \\
\hline iron $(\mathrm{mg} / \mathrm{L})$ & & 56 & 3.0 & 7.0 & 27 & 8.0 \\
\hline manganese $(\mu \mathrm{g} / \mathrm{L})$ & & 22 & 1.0 & 1.0 & 1.0 & 1.0 \\
\hline bromide (mg/L) & & 11 & 0.01 & 0.01 & 0.01 & 0.01 \\
\hline $\begin{array}{l}\text { alkalinity }\left(\text { as } \mathrm{CaCO}_{3}\right) \\
(\mathrm{mg} / \mathrm{L})\end{array}$ & & 100 & 0.1 & 1.4 & 5.2 & 1.7 \\
\hline Nutrients $(m g / L):$ & 8 & & & & & \\
\hline ammonium-nitrogen & & 50 & 0.02 & 0.02 & 0.02 & 0.02 \\
\hline nitrite-nitrogen & & 13 & 0.01 & 0.02 & 0.02 & 0.02 \\
\hline nitrite-nitrogen + nitrate-nitrogen & & 25 & 0.05 & 0.05 & 0.05 & 0.05 \\
\hline phosphorus, total dissolved & & 25 & 0.01 & 0.01 & 0.02 & 0.02 \\
\hline$D O C(m g / L):$ & 9 & 89 & 0.1 & 0.1 & 4.6 & 0.4 \\
\hline VOCs - Field $(\mu g / L)$ & 7 & & & & & \\
\hline toluene & & 14 & 0.2 & 0.4 & 0.4 & 0.4 \\
\hline benzene & & 14 & 0.2 & 0.2 & 0.2 & 0.2 \\
\hline methylene chloride & & 57 & 0.2 & 0.2 & 3.4 & 1.8 \\
\hline xylene & & 14 & 0.2 & 0.4 & 0.4 & 0.4 \\
\hline$V O C s-\operatorname{Trip}(\mu g / L)$ & 6 & & & & & \\
\hline toluene & & 33 & 0.2 & 0.3 & 0.5 & 0.4 \\
\hline
\end{tabular}

equipment or both. Dissolved manganese, potassium nitrite-Nitrogen plus nitrate-Nitrogen or ammoniumNitrogen plus organic-Nitrogen (both dissolved and total) were not detected in the surface-water field blanks, nor were all but two of the schedule 2001/2010 pesticides, nor any schedule 2050/2051 pesticides.

For ground-water field blanks, the analytes detected and the percentage of detections were very similar to the pattern found in surface-water field blanks. That is, the most frequently detected constituents were alkalinity as $\mathrm{CaCO}_{3}$ (100 percent), calcium, silica, and DOC (all 89 percent), methylene chloride (57 percent), iron (56 percent), and ammonium-Nitrogen (50 percent). The median concentrations for all detections were always less than a factor of 10 above the method reporting limit and were usually only twoto three-fold higher. Silica had the highest concentra- tion with respect to the reporting limit (450-fold higher). Sources of these inorganic constituents and DOC were assumed to be the same as those for surfacewater blanks, that is, inadequate cleaning of the sampling equipment, filtration equipment, or both. Methylene chloride was most likely introduced with the concentrated hydrochloric acid used for sample and blank preservation (T.L. Miller, U.S. Geological Survey, written commun., 1996). Also, large volumes of this solvent were used at the NWQL for some analytical methods, leading to potential contamination of VOC samples (M.W. Sandstrom, U.S. Geological Survey, written commun., 1997). Methylene chloride was both the most frequently detected compound in field blanks ( 4 out of 7 blanks) and was also associated with the highest concentration relative to the reporting limit (17-fold higher) among the VOCs. For the VOC trip 
blanks, toluene was the only target analyte detected and it was detected in two of eight trip blanks. The highest detected concentration was 2.75 -fold higher than the reporting limit. The source of this compound in the trip blanks is uncertain but might be associated with long storage of these blanks prior to field sampling because it was detected only infrequently in the field blanks:

Toluene is also used in some adhesives, notably electrical tape (E.T. Furlong, U.S. Geological Survey, written commun., 1997), which was used in the sampling vehicles. Thus, there was likely very little contamination during sample and blank shipment and storage. Potassium, ortho-Phosphorus, ammonium-Nitrogen plus organic-Nitrogen, and pesticides were not detected, nor were all but four VOCs in the ground-water blanks.

\section{Field Replicates of Surface and Ground Water}

The variability between replicates was represented both as the percent difference, which is the absolute difference between duplicates divided by the average of the duplicates times 100, and in terms of absolute concentration units. For surface water, the median percent difference between replicates ranged from 0 percent for several analytes to 16 percent for simazine from the schedule 2001/2010 pesticide schedule (table 2). The maximum percent difference was 100 percent or higher for several nutrient analytes (nitriteNitrogen and all phosphorus forms) although the median percent differences were all 13 percent or less. In general, nutrient species that had relatively high median percent differences between replicates often had relatively small median absolute concentration differences between replicates.

The median percent difference for replicates of ground water ranged from 0 percent for several constituents to 67 percent for ortho-Phosphorus. Maximum variability as percent difference ranged from 1.1 percent for silica to 86 percent for ammonium-Nitrogen, which was somewhat lower than for surface water. This was expected because the ground-water replicates were all closely spaced sequential samples from a relatively slow-flowing pump whereas the surface-water samples were a mixture of sequential and concurrent samples from a more heterogenous source-flowing river water. Some of the largest maximum percent differences were associated with very small absolute concentration differences or concentrations that were near the reporting limits or both.

\section{Field Replicates and Splits of Bed Sediment}

For duplicate and split samples of bed sediment, the average percent difference was calculated as for duplicate water samples. In some cases where triplicate samples were available, the relative standard deviation was calculated as the standard deviation divided by the mean times 100 . The average of the median percent and absolute differences for all sets of replicates and splits analyzed for trace organic compounds was one to four orders of magnitude higher than the average of the median percent and absolute differences for trace inorganic constituents (table 3 ). For every analyte group, the percent and absolute difference between splits was similar but was slightly higher than that between replicates. Thus, sampling alone was not a major source of variability in the analysis of constituents in bed sediment. As expected, individual constituents present at the microgram per gram $\left(\mu \mathrm{g} \cdot \mathrm{g}^{-1}\right)$ level (trace organic compounds and some trace inorganic constituents) had a higher average median variability compared to those present at the weight percent level (some trace inorganic constituents). However, the variability between replicates and between splits reported for some of the phthalates and PAHs greatly exceeded that reported for intrinsic method performance (Furlong and others, 1996). The cause of these large differences is likely the field sampling method used to collect replicates and to sub-sample split samples from a composite sample. In the case of the replicates, samples were collected and processed sequentially, endeavoring to sample the same specific sites in the river reach each time. The variability reported largely reflects the ability to sequentially sample a river reach and can be expected to be relatively large. In the case of split samples, samples were taken sequentially out of a large, composite sample. Despite rigorous mixing during subsampling, the second split sample generally appeared to have more sand-sized particles. Thus, the split samples were probably not identical in terms of particle-size distributions and therefore would have relatively large variability in measured trace organic compounds which are associated largely with the fines (silts and clays).

Finally, contamination in the field or laboratory could also explain some of the large variabilities observed for the phthalates.

Although replicate and split concentrations were not available for some trace organic compounds, analytical difficulties may have compromised some of the 
Table 2. Precision of field replicate samples of surface and ground water

[All data is given in concentration units. $\mathrm{N}$, number of sets; min, minimum observed value or concentration; max, maximum observed value or concentration; med, median observed value or concentration; $\mathrm{mg} / \mathrm{L}$, milligrams per liter; $\mu \mathrm{g} / \mathrm{L}$, micrograms per liter $\mathrm{CaCO}_{3}$, calcium carbonate; $\mathrm{DOC}$, 'dissolved organic carbon; SOC, suspended organic carbon]

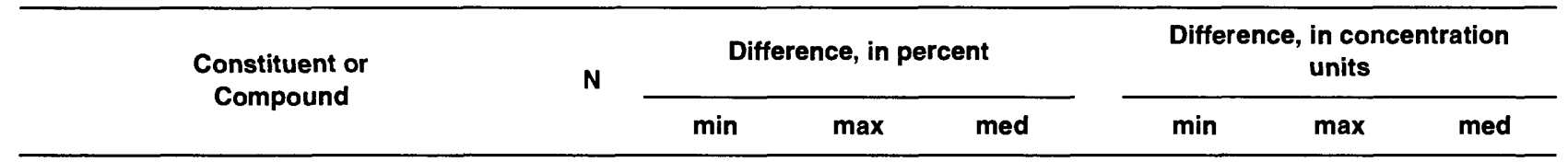

\section{Surface Water}

Major Ions:

calcium $(\mathrm{mg} / \mathrm{L})$
magnesium $(\mathrm{mg} / \mathrm{L})$
sodium $(\mathrm{mg} / \mathrm{L})$
potassium $(\mathrm{mg} / \mathrm{L})$
chloride $(\mathrm{mg} / \mathrm{L})$
sulfate $(\mathrm{mg} / \mathrm{L})$
fluoride $(\mathrm{mg} / \mathrm{L})$
silica $(\mathrm{mg} / \mathrm{L})$
iron, dissolved $(\mu \mathrm{g} / \mathrm{L})$
manganese, dissolved $(\mu \mathrm{g} / \mathrm{L})$
alkalinity $\left(\right.$ as $\left.\mathrm{CaCO}_{3}\right) \quad(\mathrm{mg} / \mathrm{L})$

$\begin{array}{lllllll}27 & 0 & 7.4 & 1.2 & 0 & 23 & 1.0 \\ 27 & 0 & 5.6 & 0 & 0 & 9.8 & 0 \\ 27 & 0 & 11 & 0 & 0 & 4.0 & 0 \\ 27 & 0 & 22 & 3.3 & 0 & 0.9 & 0.1 \\ 26 & 0 & 40 & 2.9 & 0 & 10 & 1.0 \\ 26 & 0 & 13 & 0.6 & 0 & 6.1 & 0.05 \\ 20 & 0 & 40 & 0 & 0 & 0.1 & 0 \\ 27 & 0 & 9.5 & 1.1 & 0 & 7.1 & 0.1 \\ 27 & 0 & 61 & 7.4 & 0 & 150 & 3.0 \\ 27 & 0 & 15 & 0 & 0 & 11 & 0 \\ 26 & 0 & 6.6 & 0 & 0 & 89 & 0\end{array}$

Nutrients $(m g / L)$ :

ammonium-nitrogen
nitrite-nitrogen
ammonium-nitrogen + organic-
nitrogen, dissolved
ammonium-nitrogen + organic-
nitrogen, total
nitrite-nitrogen + nitrate-nitrogen
phosphorus, total
phosphorus, dissolved
phosphorus, ortho
$O C(m g / L)$ :
( $m g / L)$ :

$\begin{array}{rrrrrrr}26 & 0 & 86 & 0 & 0 & 0.03 & 0 \\ 15 & 0 & 143 & 0 & 0 & 0.05 & 0 \\ 26 & 0 & 40 & 12 & 0 & 0.2 & 0.1\end{array}$

27

0

55

8.0

0

0.4

0.1

20

0

$$
62
$$

$$
0.0
$$

100

13

0.12

0

$25 \quad 0$

120

$$
9.5
$$

$$
0
$$

6.9

2.5

$33 \quad 6.6$

6.6

22
9.5

16

4.8
0
0

0.040

0.002

prometon

20

9.5

4.8

0.002

0.001 
Table 2. Precision of field replicate samples of surface and ground water-Continued

\begin{tabular}{|c|c|c|c|c|c|c|c|}
\hline \multirow{2}{*}{$\begin{array}{l}\text { Constituent or } \\
\text { Compound }\end{array}$} & \multirow[t]{2}{*}{$\mathbf{N}$} & \multicolumn{3}{|c|}{ Difference, in percent } & \multicolumn{3}{|c|}{$\begin{array}{l}\text { Difference, in concentration } \\
\text { units }\end{array}$} \\
\hline & & $\min$ & $\max$ & med & $\min$ & $\max$ & med \\
\hline cyanazine & 5 & 0 & 18 & 8.0 & 0.001 & 0.010 & 0.006 \\
\hline metolachlor & 6 & 0 & 18 & 3.0 & 0 & 0.020 & 0.001 \\
\hline atrazine & 8 & 0 & 82 & 9.7 & 0 & 0.020 & 0.005 \\
\hline alachlor & 3 & 0 & 18 & 11 & $\dot{0}$ & 0.001 & 0.001 \\
\hline metribuzin & 1 & 5.1 & 5.1 & 5.1 & 0.001 & 0.001 & 0.001 \\
\hline EPTC & 1 & 15 & 15 & 15 & 0.003 & 0.003 & 0.003 \\
\hline
\end{tabular}

Ground Water

Major Ions:

\begin{tabular}{|c|c|c|c|c|c|c|c|}
\hline calcium (mg/L) & 8 & 0 & 3.7 & 0 & 0 & 1.0 & 0 \\
\hline magnesium $(\mathrm{mg} / \mathrm{L})$ & 8 & 0 & 4.7 & 0 & 0 & 1.0 & 0 \\
\hline sodium $(\mathrm{mg} / \mathrm{L})$ & 8 & 0 & 7.4 & 0.6 & 0 & 1.0 & 0.05 \\
\hline potassium (mg/L) & 8 & 0 & 50 & 0 & 0 & 0.2 & 0 \\
\hline chloride (mg/L) & 8 & 0 & 7.4 & 4.6 & 0 & 1.0 & 0.15 \\
\hline sulfate $(\mathrm{mg} / \mathrm{L})$ & 8 & 0 & 6.2 & 0 & 0 & 1.0 & 0.3 \\
\hline fluoride $(\mathrm{mg} / \mathrm{L})$ & 4 & 0 & 67 & 0 & 0 & 0.1 & 0 \\
\hline silica $(\mathrm{mg} / \mathrm{L})$ & 8 & 0 & 1.1 & 0 & 0 & 0.1 & 0 \\
\hline bromide (mg/L) & 8 & 0 & 67 & 18 & 0 & 0.02 & 0.01 \\
\hline iron, dissolved $(\mu \mathrm{g} / \mathrm{L})$ & 6 & 0 & 7.4 & 1.4 & 0 & 20 & 1.0 \\
\hline manganese, dissolved $(\mu \mathrm{g} / \mathrm{L})$ & 6 & 0 & 5.0 & 0 & 0 & 40 & 0 \\
\hline alkalinity $\left(\right.$ as $\left.\mathrm{CaCO}_{3}\right) \quad(\mathrm{mg} / \mathrm{L})$ & 8 & 0 & 12 & 1.9 & 0 & 12 & 1.3 \\
\hline \multicolumn{8}{|l|}{ rients $(m g / L):$} \\
\hline ammonium-nitrogen & 7 & 0 & 86 & 11 & 0 & 0.03 & 0.01 \\
\hline $\begin{array}{l}\text { ammonium-nitrogen + organic- } \\
\text { nitrogen, dissolved }\end{array}$ & 3 & 0 & 50 & 0 & 0 & 0.2 & 0 \\
\hline nitrite-nitrogen + nitrate-nitrogen & 3 & 0 & 8.0 & 2.5 & 0.1 & 0.1 & 0.1 \\
\hline phosphorus, dissolved & 1 & 0 & 0 & 0 & 0 & 0.01 & 0.01 \\
\hline phosphorus, ortho & 1 & 67 & 67 & 67 & 0.01 & 0.01 & 0.01 \\
\hline$C(m g / L):$ & 8 & 0 & 12 & 8.0 & 0 & 0.2 & 0.1 \\
\hline \multicolumn{8}{|l|}{ ticides - 2001/2010 $(\mu \mathrm{g} / \mathrm{L})$ : } \\
\hline atrazine & 1 & 13 & 15 & 14 & 0.001 & 0.001 & 0.001 \\
\hline
\end{tabular}




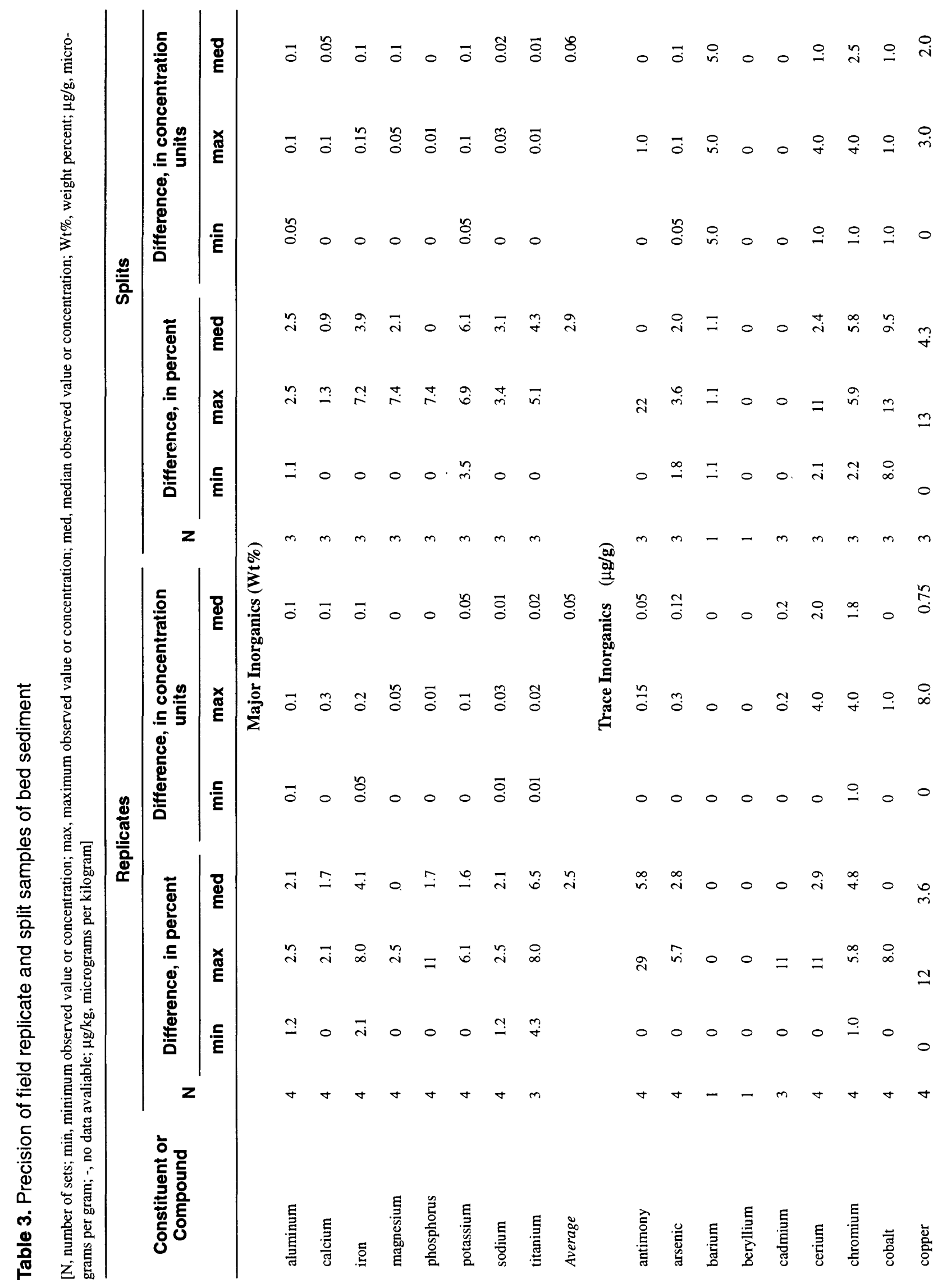

10 Results of the Quality-Control Sampling of Water, Bed Sediment, and Tissue in the Western Lakes Michigan Drainages Study Unit of the National Water Quality Assessment Program 


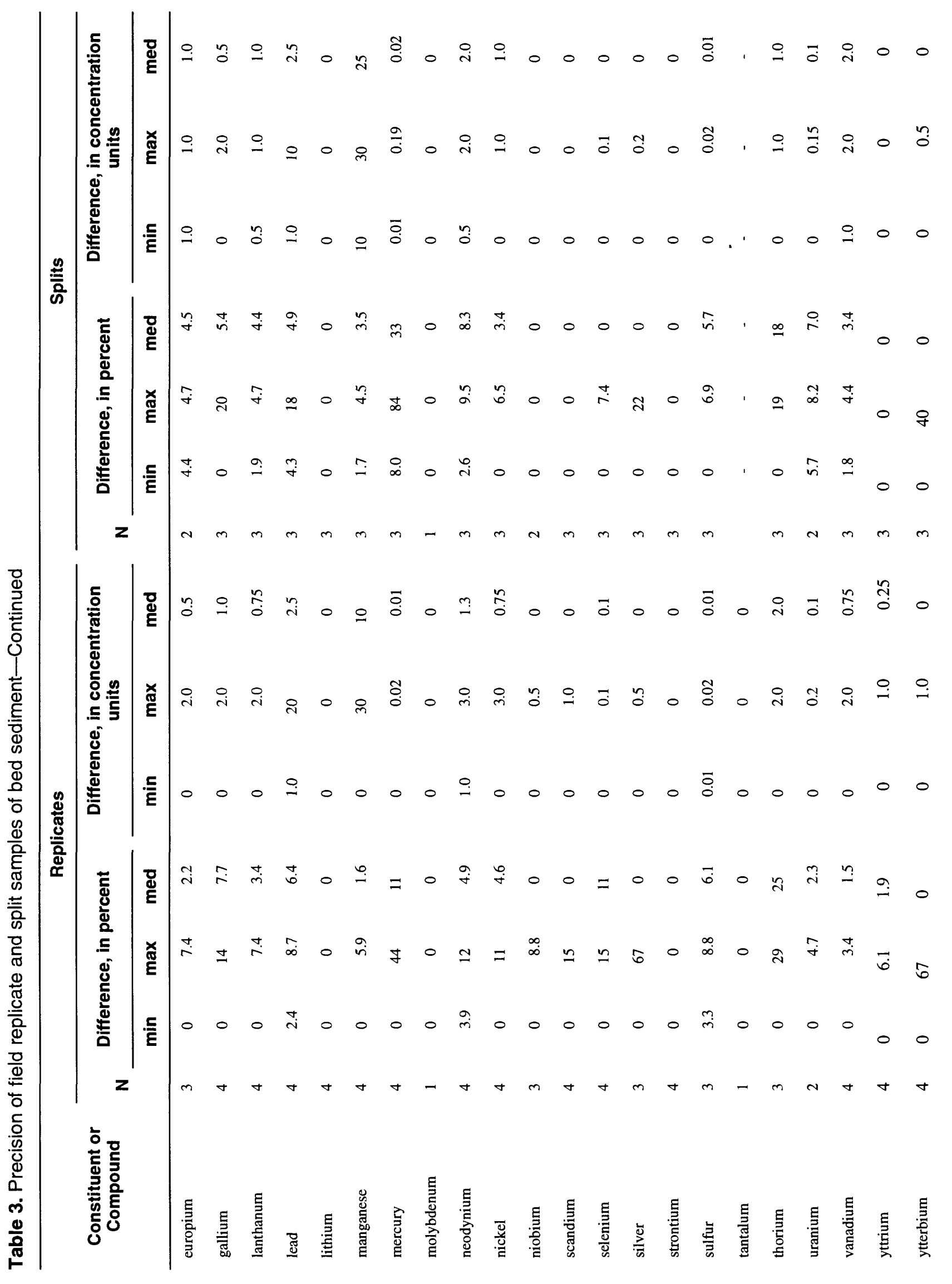




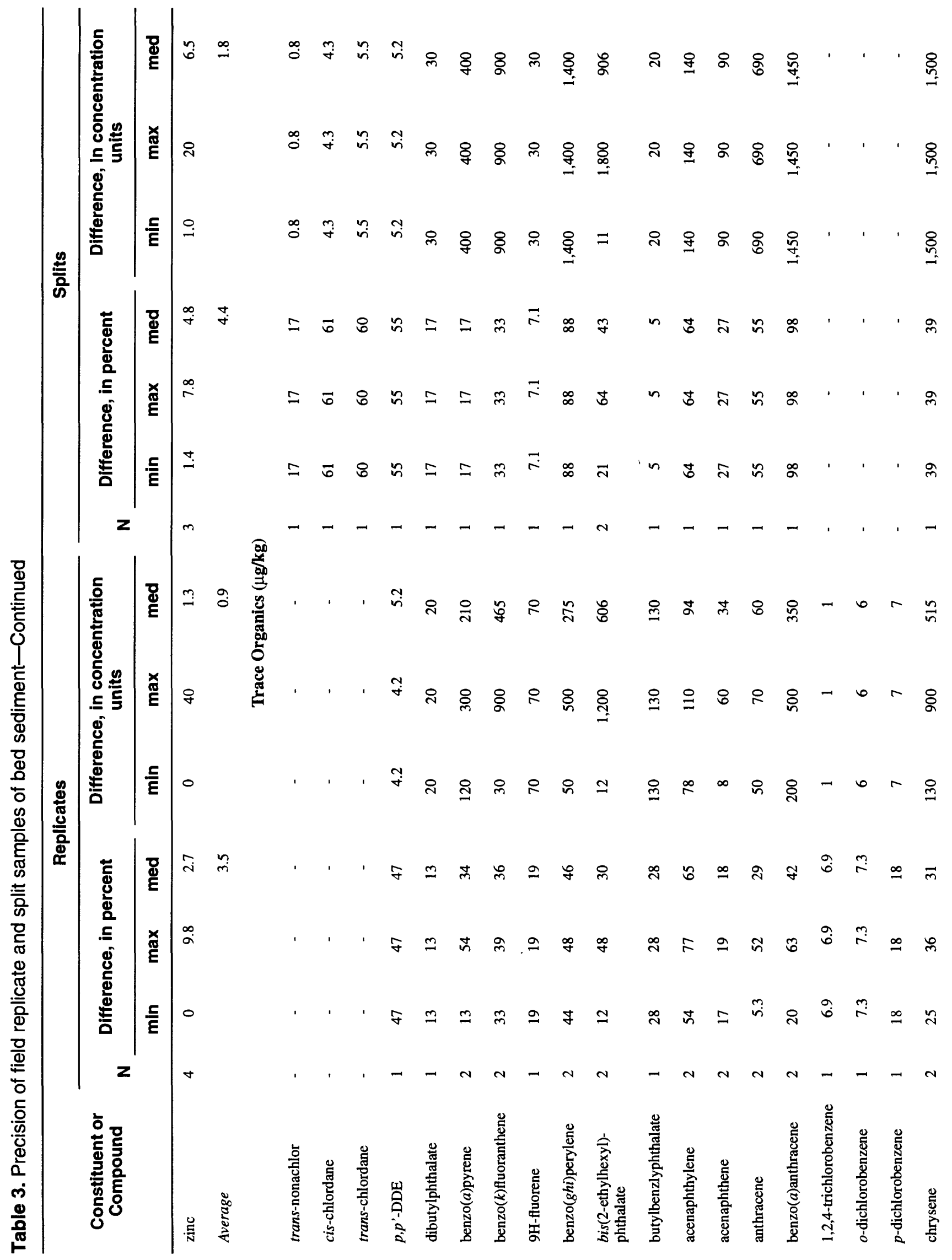




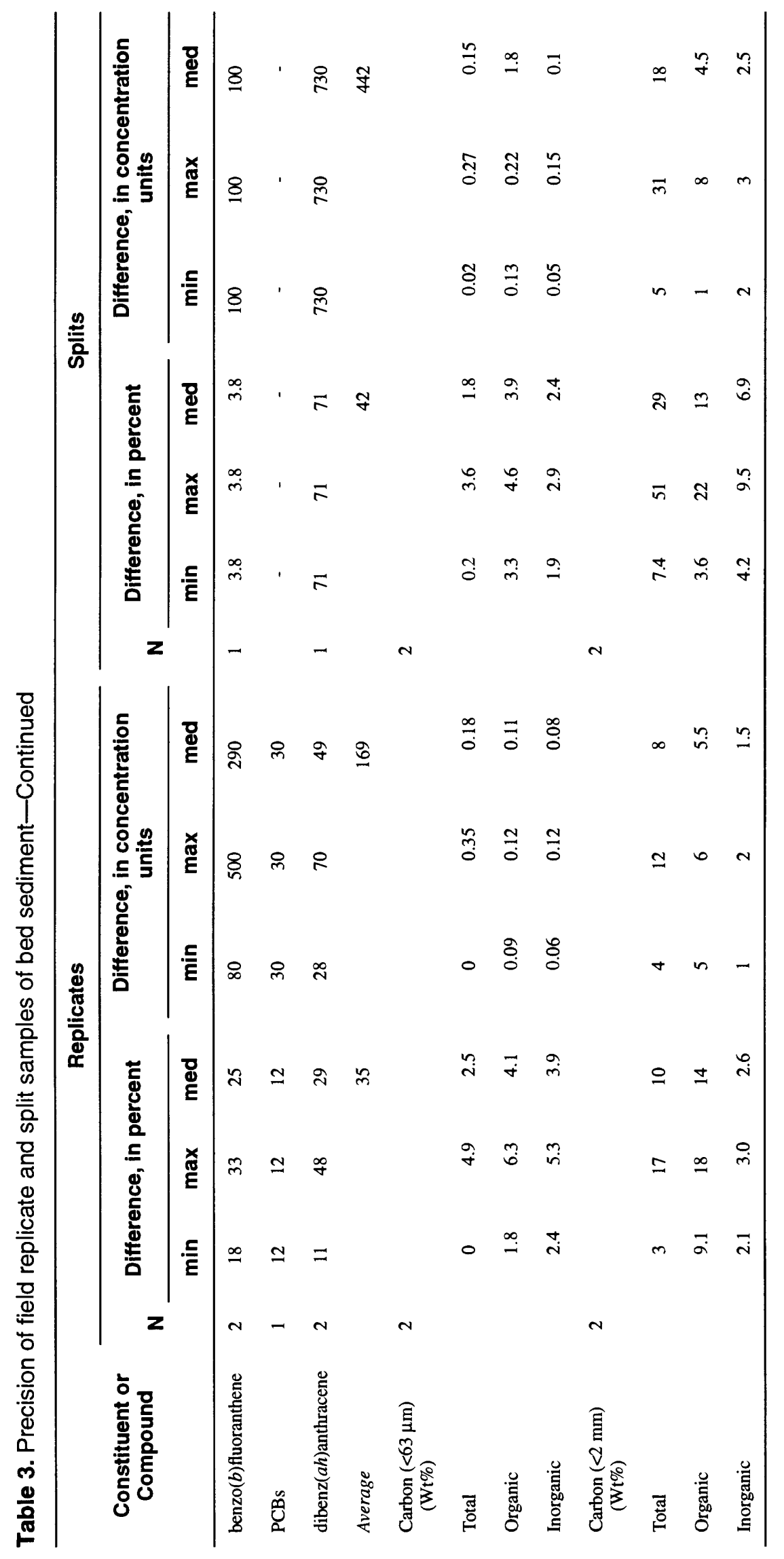


environmental data for these constituents (Foreman and others, 1995). For example, low recoveries were noted for certain target analytes in some of the sample sets, due to sample preparation. This problem has since been corrected and should not affect future samples that will be analyzed using the analytical methods for bed sediments. Also, thermal degradation in the injection port of the gas chromatograph (Foreman and Gates, 1997) affected analyses of certain compounds including:

- $o, p^{\prime}$-DDT (converts to $o, p^{\prime}$-DDD)

- $p, p^{\prime}$-DDT (converts to $p, p^{\prime}$-DDD)

- endrin (converts to endrin aldehyde)

- endrin aldehyde (converts to endrin ketone)

- methoxychlors (convert to other compounds)

Because of this problem, with respect to the compounds in the DDT family, concentrations were summed as follows:

- $\Sigma\left(o, p^{\prime}-\mathrm{DDT}\right.$ family $)=\left(o, p^{\prime}-\mathrm{DDT}\right)+\left(o, p^{\prime}-\right.$ $\mathrm{DDD})+\left(o, p^{\prime}-\mathrm{DDE}\right)$

- $\Sigma\left(p, p^{\prime}-\mathrm{DDT}\right.$ family $)=\left(p, p^{\prime}-\mathrm{DDT}\right)+\left(p, p^{\prime}-\right.$ $\mathrm{DDD})+\left(p, p^{\prime}-\mathrm{DDE}\right)$

For total, organic, and inorganic carbon in bed sediment, in general, variability in terms of percent and absolute difference between replicates was similar to that between splits; therefore, sampling was eliminated as a major source of variability. All median percent and absolute differences for both replicates and splits were somewhat higher for the $<2 \mathrm{~mm}$ fraction (sampled for trace organic compounds) compared to the $<63 \mu \mathrm{m}$ fraction (sampled for trace inorganic constituents). This was expected because the larger sieve would necessarily result in a more heterogenous sample due to inclusion of relatively rare high-carbon components including small twigs, leaf parts, and small benthic animals or low-carbon constituents including sand and gravel. As with the trace inorganic and organic components, there was a similar, though slightly greater, variability within the splits compared to that within the replicates, which indicates that the sampling was not a large source of variability.

\section{Field Replicates of Tissue}

Replicate samples of tissue consisted of either caddis fly (Hydropsyche spp., Ceratopsyche spp., or
Cheumatopsyche spp.) or stone fly (Acroneuria sp.), analyzed for inorganic constituents, and white sucker (Catostomas commersoni), analyzed for trace organic compounds, as stated previously. In tissue samples, concentrations of trace inorganic constituents are reported in micrograms per gram dry weight of tissue $\left(\mu \mathrm{g} \cdot \mathrm{g}^{-1}\right)$ and trace organic compounds are reported in micrograms per kilogram wet tissue $\left(\mu \mathrm{g} \cdot \mathrm{kg}^{-1}\right)$. For trace inorganic constituents, the median difference ranged from 0 percent for mercury and uranium to 29 percent for cadmium (table 4). Median absolute differences ranged from $0 \mu \mathrm{g} \cdot \mathrm{g}^{-1}$ for mercury and uranium to $210 \mu \mathrm{g} \cdot \mathrm{g}^{-1}$ for iron. Replicate analyses were available for only one trace organic compound - $p, p^{\prime}$-DDE. Triplicate concentrations were $6.5,5.5$ and $<5.0 \mu \mathrm{g} \cdot \mathrm{kg}^{-1}$, which corresponded to a minimum percent and absolute difference of 15 percent and $0.9 \mu \mathrm{g} \cdot \mathrm{kg}^{-1}$, respectively. Total lipids varied by an average of 12 percent between replicates, which corresponded to a median absolute difference of 0.4 weight percent (mass of analyte divided by mass of wet tissue times 100 ).

\section{Field Matrix Spikes in Surface Water}

Two sets of schedule 2001/2010 pesticide field matrix spikes and one set of schedule 2050/2051 pesticide field matrix spikes yielded data amenable to determine the recovery and precision (2001/2010 pesticides only) of these pesticide analyses for surface water.

Although more putative spiked samples were prepared and analyzed, it was apparent that these samples either had not been spiked or were spiked at concentrations that were outside the analytical range of the methods. For schedule 2001/2010 pesticides, the average percent difference between duplicate spikes ranged an order of magnitude - from 1.5 percent for pronamide to 15 percent for metribuzin (table 5). The average percent recovery ranged from 13 percent for propargite to 116 percent for cyanazine. Compounds with relatively low average recoveries included $p, p^{\prime}-\mathrm{DDE}$ ( 66 percent), metribuzin (60 percent), and propargite (13 percent). These average recoveries were roughly similar to recoveries reported in reagent samples spiked at the 0.1 $\mu \mathrm{g} \cdot \mathrm{L}^{-1}$ level except for propargite, which had an average recovery of 59 percent in reagent samples (Zaugg and others, 1995). Thus, except for propargite recovery, it appears these relatively low recoveries were not due to decomposition or matrix effects but rather to intrinsic method performance. In the case of metribuzin, low recoveries could be due to incomplete 
Table 4. Precision of field replicate samples of tissue

[N; number of sets; min, minimum observed value or concentration; max, maximum observed value or concentration; med, median observed value or concentration; $\mu \mathrm{g} / \mathrm{g}$, micrograms per gram dry tissue (trace inorganics); Wt\%, weight percent; $\mu \mathrm{g} / \mathrm{kg}$, micrograms per kilogram wet tissue

\begin{tabular}{|c|c|c|c|c|c|c|c|}
\hline \multirow{2}{*}{$\begin{array}{l}\text { Constituent or Com- } \\
\text { pound }\end{array}$} & \multirow{2}{*}{$\mathbf{N}$} & \multicolumn{3}{|c|}{ Difference, in percent } & \multicolumn{3}{|c|}{ Difference, in concentration units } \\
\hline & & $\min$ & $\max$ & med & $\min$ & $\max$ & med \\
\hline \multicolumn{8}{|c|}{ Trace Inorganics $(\mu \mathrm{g} / \mathrm{g})$} \\
\hline aluminum & 7 & 0.2 & 44 & 12 & 1.0 & 231 & 49 \\
\hline arsenic & 5 & 0 & 50 & 18 & 0 & 0.4 & 0.2 \\
\hline barium & 7 & 0.2 & 30 & 5.3 & 0.1 & 4.0 & 1.2 \\
\hline boron & 7 & 0 & 108 & 19 & 0 & 1.8 & 0.7 \\
\hline cadmium & 1 & 29 & 29 & 29 & 0.1 & 0.1 & 0.1 \\
\hline chromium & 7 & 4.5 & 33 & 17 & 0.1 & 0.5 & 0.3 \\
\hline cobalt & 5 & 5.7 & 16 & 15 & 0 & 0.3 & 0.1 \\
\hline copper & 7 & 0 & 18 & 8.8 & 0 & 2.8 & 1.6 \\
\hline iron & 7 & 5.6 & 137 & 13 & 27 & 411 & 210 \\
\hline lead & 5 & 6.1 & 18 & 15 & 0 & 0.2 & 0.1 \\
\hline manganese & 7 & 0.9 & 88 & 17 & 30 & 930 & 92 \\
\hline mercury & 2 & 0 & 0 & 0 & 0 & 0 & 0 \\
\hline molybdenum & 5 & 8.7 & 22 & 15 & 0.1 & 0.2 & 0.1 \\
\hline nickel & 7 & 14 & 40 & 18 & 0.1 & 0.6 & 0.4 \\
\hline selenium & 5 & 0 & 45 & 14 & 0 & 0.7 & 0.2 \\
\hline strontium & 7 & 0 & 36 & 8.2 & 0 & 1.0 & 0.9 \\
\hline uranium & 1 & 0 & 0 & 0 & 0 & 0.1 & 0 \\
\hline vanadium & 5 & 4.5 & 26 & 10 & 0.1 & 0.4 & 0.3 \\
\hline zinc & 7 & 2.7 & 13 & 3.4 & 4.0 & 26 & 7.0 \\
\hline Water $(\mathrm{Wt} \%)$ & 7 & 1.6 & 3.4 & 1.9 & 0.2 & 1.8 & 1.5 \\
\hline \multicolumn{8}{|c|}{ Trace Organics $(\mu \mathrm{g} / \mathrm{kg})$} \\
\hline$p, p^{\prime}-\mathrm{DDE}$ & 1 & 15 & 15 & 15 & 0.9 & 0.9 & 0.9 \\
\hline Total Lipids (Wt\%) & 2 & 5.0 & 18 & 12 & 0.3 & 0.5 & 0.4 \\
\hline
\end{tabular}


Table 5. Precision and recovery of field matrix spikes in surface water samples

[All data are in percent]

\begin{tabular}{|c|c|c|c|c|c|c|}
\hline \multirow{2}{*}{ Compound } & \multicolumn{2}{|c|}{$\begin{array}{c}\text { Percent } \\
\text { difference }\end{array}$} & \multirow{2}{*}{$\begin{array}{l}\text { Average } \\
\text { percent dif- } \\
\text { ference }\end{array}$} & \multicolumn{2}{|c|}{$\begin{array}{l}\text { Percent } \\
\text { recovery }\end{array}$} & \multirow{2}{*}{$\begin{array}{c}\text { Average } \\
\text { percent } \\
\text { recovery }\end{array}$} \\
\hline & Set 1 & Set 2 & & Set 1 & Set 2 & \\
\hline \multicolumn{7}{|c|}{ 2001/2010 Pesticides } \\
\hline propachlor & 9.0 & 2.7 & 5.8 & 117 & 111 & 114 \\
\hline butylate & 2.0 & 4.0 & 3.0 & 93 & 95 & 94 \\
\hline simazine & 21 & 0.69 & 11 & 103 & 98 & 100 \\
\hline prometon & 0.78 & 2.7 & 1.7 & 89 & 89 & 89 \\
\hline cyanazine & 0.96 & 1.3 & 1.2 & 134 & 98 & 116 \\
\hline fonofos & 0.17 & 4.7 & 2.4 & 83 & 83 & 83 \\
\hline$\alpha-\mathrm{HCH}$ & 0.10 & 4.8 & 2.5 & 87 & 85 & 86 \\
\hline$p, p^{\prime}-\mathrm{DDE}$ & 3.5 & 7.6 & 5.5 & 73 & 58 & 66 \\
\hline chlorpyrifos & 9.7 & 4.0 & 6.8 & 108 & 95 & 101 \\
\hline lindane & 3.1 & 4.7 & 3.9 & 88 & 83 & 85 \\
\hline dieldrin & 7.0 & 14 & 11 & 108 & 87 & 97 \\
\hline metolachlor & 0.96 & 4.7 & 2.8 & 98 & 109 & 103 \\
\hline malathion & 6.3 & 4.0 & 5.1 & 78 & 95 & 86 \\
\hline parathion & 9.0 & 2.1 & 5.5 & 117 & 62 & 90 \\
\hline diazinon & 13 & 4.0 & 8.2 & 90 & 95 & 92 \\
\hline atrazine & 11 & 4.7 & 7.8 & 119 & 97 & 108 \\
\hline alachlor & 8.6 & 4.7 & 6.6 & 91 & 103 & 97 \\
\hline metribuzin & 26 & 4.0 & 15 & 29 & 92 & 60 \\
\hline 2,6-diethylaniline & 1.4 & 3.6 & 2.5 & 79 & 77 & 78 \\
\hline trifluralin & 8.1 & 0.64 & 4.4 & 79 & 79 & 79 \\
\hline ethalfluralin & 0.96 & 4.7 & 2.8 & 94 & 88 & 91 \\
\hline phorate & 4.5 & 3.3 & 3.9 & 69 & 102 & 85 \\
\hline linuron & 0.96 & 3.3 & 2.1 & 103 & 98 & 101 \\
\hline methyl parathion & 0.10 & 4.7 & 2.4 & 86 & 85 & 85 \\
\hline EPTC & 2.0 & 4.7 & 3.3 & 93 & 88 & 90 \\
\hline pebulate & 25 & 3.3 & 14 & 73 & 95 & 84 \\
\hline tebuthiuron & 0.96 & 2.7 & 1.8 & 103 & 108 & 106 \\
\hline molinate & 4.4 & 4.7 & 4.5 & 83 & 97 & 90 \\
\hline ethoprop & 11 & 0.64 & 6.0 & 72 & 79 & 76 \\
\hline benfluralin & 12 & 4.7 & 8.5 & 85 & 88 & 87 \\
\hline terbufos & 5.1 & 4.7 & 4.9 & 90 & 88 & 89 \\
\hline pronamide & 0.35 & 2.7 & 1.5 & 72 & 97 & 84 \\
\hline
\end{tabular}


Table 5. Precision and recovery of field matrix spikes in surface water samples-Continued

\begin{tabular}{|c|c|c|c|c|c|c|}
\hline \multirow[t]{2}{*}{ Compound } & \multicolumn{2}{|c|}{$\begin{array}{c}\text { Percent } \\
\text { difference }\end{array}$} & \multirow{2}{*}{$\begin{array}{c}\text { Average } \\
\text { percent dif- } \\
\text { ference }\end{array}$} & \multicolumn{2}{|c|}{$\begin{array}{l}\text { Percent } \\
\text { recovery }\end{array}$} & \multirow{2}{*}{$\begin{array}{c}\text { Average } \\
\text { percent } \\
\text { recovery }\end{array}$} \\
\hline & Set 1 & Set 2 & & Set 1 & Set 2 & \\
\hline disulfoton & 0.96 & 4.7 & 2.8 & 103 & 90 & 97 \\
\hline triallate & 4.2 & 4.7 & 4.5 & 87 & 96 & 91 \\
\hline propanil & 0.96 & 4.7 & 2.8 & 113 & 97 & 105 \\
\hline thiobencarb & 0.96 & 4.7 & 2.8 & 131 & 97 & 114 \\
\hline DCPA & 2.0 & 4.0 & 3.0 & 92 & 92 & 92 \\
\hline pendimethalin & 0.96 & 4.7 & 2.8 & 103 & 105 & 104 \\
\hline napropamide & 4.7 & 4.7 & 4.7 & 83 & 88 & 86 \\
\hline propargite & 5.5 & 4.7 & 5.1 & 24 & 2 & 13 \\
\hline \multicolumn{7}{|c|}{ 2050/2051 Pesticides } \\
\hline bromacil & & & & 123 & & \\
\hline dicamba & & & & 65 & & \\
\hline linuron & & & & 210 & & \\
\hline propoxur & & & & 64 & & \\
\hline bentazon & & & & 123 & & \\
\hline 2,4-DB & & & & 82 & & \\
\hline fluormeturon & & & & 105 & & \\
\hline $2,4-\mathrm{D}$ & & & & 131 & & \\
\hline $2,4,5-\mathrm{T}$ & & & & 0 & & \\
\hline silvex & & & & 131 & & \\
\hline propham & & & & 241 & & \\
\hline picloram & & & & 6.1 & & \\
\hline neburon & & & & 96 & & \\
\hline methomyl & & & & 96 & & \\
\hline dinoseb & & & & 114 & & \\
\hline dichlorprop & & & & 131 & & \\
\hline carbofuran & & & & 55 & & \\
\hline bromoxynil & & & & 131 & & \\
\hline aldicarb sulfoxide & & & & 56 & & \\
\hline
\end{tabular}

collection (that is, chromatographic "breakthrough") on the solid phase extraction cartridges due to high water solubility (W.T. Foreman, U.S. Geological Survey, written commun., 1997). Interferences present in the environmental sample matrices, biasing recoveries high, might be suggested for cyanazine (134 percent in set number 1) and thiobencarb (131 percent in set number 1).
The percent recovery of schedule $2050 / 2051$ pesticides ranged from 0 percent for $2,4,5-\mathrm{T}$ to 241 percent for propham. Six of the 19 pesticides had less than 70 percent recovery and 8 had greater than 120 percent recovery. Because of the relatively poor performance of the schedule 2050/2051 pesticide method compared to that for schedule $2001 / 2010$ pesticides, a review of the method in both the laboratory and the field was done (NAWQA/NWQL Quality Assurance Committee 
for Schedule 2050/2051 Pesticide Method, U.S. Geological Survey, written commun., 1995). Pertinent among the findings is that recoveries of compounds in field matrix spikes were 5 to 10 percent lower than in laboratory spikes. This discrepancy has been corrected by communication of the need to add salt $(\mathrm{NaCl})$ as a recovery enhancer to the field matrix spikes. Also, the rate of elution (in the laboratory), the most important preparation step, was not adequately controlled in the post-July 1993 period. This would have resulted in apparent decreased recoveries of some compounds.

Also, certain compounds in the field matrix spike mixture, including silvex and picloram, were shown to be susceptible to thermal or photodegradation or both. Finally, recovery of four compounds (2,4-DB, 2,4-D, silvex and picloram) were likely underestimated for all samples analyzed prior to May 1, 1995, including the one spike set reported here, due to quantitation of only one of two elution fractions containing the compound (M.R. Burkhardt, U.S. Geological Survey, written commun., 1996). After this date, concentrations in both fractions were summed, thus complicating direct comparisons with future spike recoveries.

\section{Field Matrix Spikes in Ground Water}

Six and seven field matrix spike sets were analyzed for schedules 2001/2010 and 2050/2051 pesticides, respectively, to determine the precision and recovery of these compounds in ground water (table 6). All compounds on the 2001/2010 schedule had reasonable precision ( $<10$ percent) and recovery (between 70 and 120 percent) except permethrin, which had a slightly lower average recovery (66 percent). The median percent difference between duplicate spikes ranged from 0.6 percent for metolachlor to 9.5 percent for methyl parathion. The median recovery ranged from 66 percent for permethrin, as previously mentioned, to 104 percent for disulfoton. The average recovery of permethrin was even lower (37 percent) in reagent spiked samples $\left(0.1 \mu \mathrm{g} \cdot \mathrm{L}^{-1}\right.$ level) (Zaugg and others, 1995). Analytical interferences that may have produced high maximum recoveries might be indicated for the following compounds: tebuthiuron (144 percent), disulfoton (209 percent), DCPA (134 percent), and permethrin (151 percent maximum recovery percentage). Of these, the very unstable nature of disulfoton in solution might explain the intermittent relatively high recovery.
Seven spike sets were analyzed for the schedule 2050/2051 pesticides, but data for precision and recovery calculations were available for fewer than 5 of those sets for four compounds (propham, neburon, methomyl, and diuron) of the total of 21 compounds. The median percent difference between duplicate field spikes ranged from 9.1 percent for bentazon to 34 percent for aldicarb sulfoxide. The median percent recovery of all compounds ranged from 38 percent for 2,4DB to 109 percent for linuron. Recoveries of schedule $2050 / 2051$ pesticides in ground water were subject to the same problems mentioned above for recovery in surface water, although the average recoveries were somewhat higher in ground water.

For VOC field spikes, the median percent difference between duplicate field spikes ranged from 6.9 percent for 1,2-dichloroethane to 18 percent for MTBE. The median percent recovery ranged from 45 percent for tetrachloroethylene to 72 percent for MTBE. These recoveries are likely artificially biased approximately 20 percent low (on average) due to delivery of only approximately 80 percent of the spike mass with a micropipettor compared to a gas-tight glass syringe later specified for the method (J.S. Zogorski, U.S. Geological Survey, written commun., 1996).

\section{Surrogates in Surface and Ground Water}

For surface water, the median percent recovery for the three schedule 2001/2010 surrogate compounds ranged from 96 percent to 107 percent, which is generally much better than the median recovery for the two schedule 2050/2051 compounds with median percent recoveries of 43 percent and 30 percent (table 7). This was in keeping with the known problems with the schedule 2050/2051 methods mentioned previously. In the case of the low median recoveries for the schedule 2050/2051 pesticides, sub-optimal intrinsic method performance rather than sample handling mistakes is the probable cause. Percent recoveries for the pesticide surrogates in ground water were generally similar to those in surface water, with relatively high recoveries for the three schedule 2001/2010 surrogates (range of 91 to 98 percent) and lower recoveries for the two schedule 2050/2051 surrogates ( 23 percent and 71 percent). Toluic acid was later deleted from the method because of poor performance (NAWQA/NWQL Quality Assurance Committee for Schedule 2050/2051 Pesticide Method, U.S. Geological Survey, written commun., 1995). 
Table 6. Precision and recovery of field matrix spikes in ground water samples

[Difference and recovery data are in percent. N, number of spike sets; min, minimum observed value or concentration; max, maximum observed value or concentration; med, median observed value or concentration; VOCs, volatile organic compounds]

\begin{tabular}{|c|c|c|c|c|c|c|c|}
\hline \multirow{2}{*}{ Compound } & \multirow{2}{*}{$\mathbf{N}$} & \multicolumn{3}{|c|}{$\begin{array}{l}\text { Difference between dupli- } \\
\text { cate spikes }\end{array}$} & \multicolumn{3}{|c|}{ Recovery } \\
\hline & & $\min$ & $\max$ & med & $\min$ & $\max$ & med \\
\hline 2001/2010 Pesticides: & 6 & & & & & & \\
\hline propachlor & 6 & 1.0 & 7.9 & 4.4 & 78 & 103 & 88 \\
\hline butylate & 6 & 1.4 & 9.3 & 2.6 & 80 & 100 & 89 \\
\hline simazine & 6 & 1.0 & 19 & 3.6 & 63 & 109 & 95 \\
\hline prometon & 6 & 1.0 & 13 & 5.0 & 41 & 109 & 85 \\
\hline cyanazine & 6 & 0.0 & 5.4 & 1.5 & 72 & 129 & 96 \\
\hline fonofos & 5 & 0.1 & 11 & 3.1 & 62 & 94 & 79 \\
\hline$\alpha-\mathrm{HCH}$ & 6 & 0.9 & 13 & 4.0 & 51 & 104 & 75 \\
\hline$p, p^{\prime}-\mathrm{DDE}$ & 6 & 1.6 & 7.4 & 3.1 & 53 & 88 & 70 \\
\hline chlorpyrifos & 6 & 1.0 & 19 & 4.8 & 68 & 100 & 84 \\
\hline lindane & 5 & 0.2 & 11 & 4.7 & 75 & 105 & 86 \\
\hline dieldrin & 6 & 1.0 & 9.8 & 4.5 & 79 & 110 & 88 \\
\hline metolachlor & 6 & 0.0 & 11 & 0.6 & 89 & 129 & 97 \\
\hline malathion & 6 & 0.1 & 14 & 3.0 & 55 & 109 & 90 \\
\hline parathion & 6 & 4.1 & 9.5 & 7.3 & 61 & 124 & 89 \\
\hline diazinon & 6 & 0.0 & 15 & 2.1 & 59 & 99 & 81 \\
\hline atrazine & 6 & 1.0 & 13 & 5.7 & 73 & 119 & 87 \\
\hline alachlor & 6 & 0.3 & 14 & 2.1 & 88 & 114 & 96 \\
\hline metribuzin & 6 & 0.1 & 3.8 & 1.7 & 41 & 90 & 77 \\
\hline 2,6-diethylaniline & 6 & 1.3 & 8.2 & 3.5 & 82 & 95 & 87 \\
\hline trifluralin & 6 & 2.2 & 7.8 & 4.1 & 46 & 92 & 87 \\
\hline ethalfluralin & 6 & 1.0 & 11 & 4.9 & 42 & 109 & 88 \\
\hline phorate & 6 & 0.2 & 12 & 6.3 & 25 & 96 & 85 \\
\hline linuron & 6 & 0.1 & 15 & 3.1 & 68 & 104 & 91 \\
\hline methyl parathion & 5 & 1.0 & 12 & 9.5 & 50 & 102 & 87 \\
\hline EPTC & 6 & 0.1 & 7.8 & 3.9 & 87 & 105 & 90 \\
\hline pebulate & 6 & 0.1 & 7.2 & 1.7 & 77 & 104 & 86 \\
\hline
\end{tabular}


Table 6. Precision and recovery of field matrix spikes in ground water samples-Continued

\begin{tabular}{|c|c|c|c|c|c|c|c|}
\hline \multirow{2}{*}{ Compound } & \multirow{2}{*}{$\mathbf{N}$} & \multicolumn{3}{|c|}{$\begin{array}{l}\text { Difference between dupli- } \\
\text { cate spikes }\end{array}$} & \multicolumn{3}{|c|}{ Recovery } \\
\hline & & $\min$ & $\max$ & med & $\min$ & $\max$ & med \\
\hline tebuthiuron & 6 & 0.0 & 6.6 & 3.4 & 58 & 144 & 77 \\
\hline molinate & 6 & 0.1 & 10 & 3.6 & 82 & 104 & 91 \\
\hline ethoprop & 6 & 0.1 & 7.5 & 4.6 & 73 & 109 & 90 \\
\hline benfluralin & 6 & 2.2 & 8.3 & 3.2 & 45 & 89 & 83 \\
\hline terbufos & 6 & 2.0 & 15 & 4.1 & 54 & 110 & 98 \\
\hline pronamide & 5 & 0.1 & 11 & 2.3 & 58 & 109 & 77 \\
\hline disulfoton & 6 & 0.0 & 14 & 7.6 & 17 & 209 & 104 \\
\hline triallate & 6 & 1.2 & 9.6 & 3.5 & 77 & 98 & 83 \\
\hline propanil & 6 & 1.0 & 8.6 & 4.0 & 79 & 129 & 85 \\
\hline thiobencarb & 6 & 0.1 & 13 & 1.9 & 84 & 119 & 93 \\
\hline DCPA & 5 & 0.1 & 11 & 0.9 & 91 & 134 & 98 \\
\hline pendimethalin & 6 & 0.0 & 11 & 3.2 & 39 & 100 & 86 \\
\hline napropamide & 6 & 1.0 & 7.3 & 3.4 & 79 & 110 & 96 \\
\hline propargite & 6 & 3.9 & 9.6 & 6.2 & 65 & 91 & 71 \\
\hline permethrin & 6 & 0.1 & 8.5 & 4.4 & 46 & 151 & 66 \\
\hline 2050/2051 Pesticides: & 7 & & & & & & \\
\hline bromacil & 5 & 2.0 & 81 & 17 & 41 & 83 & 62 \\
\hline dicamba & 5 & 4.7 & 35 & 20 & 36 & 91 & 57 \\
\hline linuron & 5 & 1.6 & 55 & 11 & 58 & 162 & 109 \\
\hline propoxur & 5 & 2.1 & 83 & 22 & 0 & 69 & 48 \\
\hline bentazon & 6 & 3.3 & 28 & 9.1 & 56 & 77 & 66 \\
\hline 2,4-DB & 6 & 3.2 & 141 & 18 & 25 & 51 & 38 \\
\hline fluormeturon & 6 & 1.4 & 85 & 27 & 44 & 76 & 54 \\
\hline 2,4-D & 7 & 2.1 & 29 & 14 & 46 & 91 & 70 \\
\hline $2,4,5-\mathrm{T}$ & 7 & 2.1 & 37 & 15 & 40 & 100 & 72 \\
\hline silvex & 7 & 0.8 & 35 & 17 & 58 & 81 & 66 \\
\hline propham & 3 & 6.1 & 18 & 12 & 94 & 262 & 100 \\
\hline picloram & 5 & 14 & 85 & 32 & 35 & 82 & 68 \\
\hline neburon & 4 & 2.6 & 67 & 23 & 34 & 124 & 59 \\
\hline
\end{tabular}


Table 6. Precision and recovery of field matrix spikes in ground water samples-Continued

\begin{tabular}{|c|c|c|c|c|c|c|c|}
\hline \multirow{2}{*}{ Compound } & \multirow{2}{*}{$\mathbf{N}$} & \multicolumn{3}{|c|}{$\begin{array}{l}\text { Difference between dupli- } \\
\text { cate spikes }\end{array}$} & \multicolumn{3}{|c|}{ Recovery } \\
\hline & & $\min$ & $\max$ & med & $\min$ & $\max$ & med \\
\hline methomyl & 3 & 9.2 & 14 & 12 & 37 & 72 & 59 \\
\hline fenuron & 5 & 0.6 & 72 & 15 & 55 & 81 & 77 \\
\hline diuron & 4 & 5.8 & 63 & 9.4 & 30 & 63 & 44 \\
\hline dinoseb & 7 & 2.1 & 38 & 14 & 42 & 80 & 69 \\
\hline dichlorprop & 7 & 0.9 & 33 & 26 & 55 & 86 & 76 \\
\hline carbofuran & 7 & 0.5 & 73 & 17 & 32 & 94 & 53 \\
\hline bromoxynil & 6 & 0.9 & 31 & 27 & 0 & 78 & 68 \\
\hline aldicarb sulfoxide & 5 & 28 & 48 & 34 & 23 & 93 & 46 \\
\hline VOCs: & 6 & & & & & & \\
\hline dichlorobromo-methane & 6 & 0 & 26 & 11 & 50 & 64 & 61 \\
\hline carbon tetrachloride & 6 & 8.7 & 29 & 13 & 48 & 65 & 51 \\
\hline 1,2-dichloroethane & 6 & 0 & 24 & 6.9 & 57 & 77 & 62 \\
\hline bromoform & 6 & 0 & 26 & 12 & 46 & 71 & 55 \\
\hline chlorodibromo-methane & 6 & 0 & 26 & 12 & 50 & 68 & 61 \\
\hline ethylbenzene & 6 & 7.4 & 19 & 15 & 44 & 60 & 53 \\
\hline tetrachloroethylene & 6 & 0 & 20 & 9.1 & 38 & 54 & 45 \\
\hline dichloroethylene & 6 & 0 & 20 & 11 & 37 & 63 & 49 \\
\hline trichloroethane & 6 & 0 & 20 & 12 & 48 & 65 & 56 \\
\hline 1,4-dichloro-benzene & 6 & 0 & 22 & 10 & 57 & 76 & 63 \\
\hline vinylchloride & 6 & 0 & 18 & 10 & 39 & 54 & 47 \\
\hline trichloroethylene & 6 & 0 & 18 & 11 & 50 & 67 & 55 \\
\hline MTBE & 4 & 6.1 & 75 & 18 & 46 & 85 & 72 \\
\hline
\end{tabular}


Table 7. Recovery of trace organic surrogates in surface and ground water samples

[All recovery data are in percent. $\mathrm{N}$, number of surrogate samples; min, minimum observed value or concentration; max, maximum observed value or concentration; med, median observed value or concentration; $\mathrm{HCH}$, hexachlorocyclohexane; BDMC, 4-Bromo-3,5-dimethyl phenyl-nmethyl carbamate; VOCs, volatile organic compounds]

\begin{tabular}{|c|c|c|c|c|}
\hline \multirow{2}{*}{ Compound } & \multirow{2}{*}{$\mathbf{N}$} & \multicolumn{3}{|c|}{ Recovery } \\
\hline & & $\min$ & $\max$ & med \\
\hline \multicolumn{5}{|c|}{ Surface Water Pesticides } \\
\hline \multicolumn{5}{|l|}{ 2001/2010: } \\
\hline [D10]Diazinon & 174 & 8 & 170 & 100 \\
\hline Terbuthylazine & 175 & 12 & 356 & 107 \\
\hline$[\mathrm{D} 6] \alpha-\mathrm{HCH}$ & 174 & 11 & 168 & 96 \\
\hline \multicolumn{5}{|l|}{ 2050/2051: } \\
\hline Toluic Acid & 16 & 2 & 94 & 43 \\
\hline BDMC & 105 & 1 & 102 & 30 \\
\hline \multicolumn{5}{|c|}{ Ground Water Pesticides } \\
\hline \multicolumn{5}{|l|}{ 2001/2010: } \\
\hline [D10]Diazinon & 126 & 19 & 185 & 91 \\
\hline Terbuthylazine & 126 & 19 & 127 & 98 \\
\hline$[\mathrm{D} 6] \alpha-\mathrm{HCH}$ & 125 & 17 & 168 & 94 \\
\hline \multicolumn{5}{|l|}{ 2050/2051: } \\
\hline Toluic Acid & 9 & 5 & 34 & 23 \\
\hline BDMC & 106 & 4 & 148 & 71 \\
\hline \multicolumn{5}{|c|}{ Ground Water VOCs } \\
\hline [D4]1,2-Dichloroethane & 55 & 88 & 111 & 100 \\
\hline [D8]Toluene & 63 & 88 & 106 & 97 \\
\hline 1,4-Bromofluorobenzene & 53 & 85 & 120 & 98 \\
\hline
\end{tabular}

\section{Surrogates in Bed Sediment and Tissue}

The median percent recovery for the six trace organic surrogates in bed sediment ranged from 55 percent for 3,5-dichlorobiphenyl to 68 percent for [D14]nitrobenzene (table 8). The recoveries of the semi-volatile organic compounds ([D14]Terphenyl, 2Fluorobiphenyl, and [D5]Nitrobenzene) were similar to those published for all bed sediments (Furlong and others, 1996). As mentioned previously for trace organic target analytes in bed sediment, the low recovery of some surrogates, the organochlorine com- pounds, was due to known sample-handling difficulties and has since been corrected. Thus, comparison of these recoveries with those determined in the future will be somewhat more complicated. In tissues, median recoveries for the two trace organic surrogates were somewhat higher than those in bed sediment, being 79 percent and 100 percent for 3,5-dichlorobiphenyl and [D6] $\alpha-\mathrm{HCH}$ ([D6] $\alpha-$ Hexachlorocyclohexane), respectively.

Table 8. Recovery of trace organic surrogates in bed sediment and tissue samples

[All recovery data are in percent. $\mathrm{N}$, number of surrogate samples; min, minimum observed value or concentration; max, maximum observed value or concentration; med, median observed value or concentration; $\mathrm{HCH}$, hexachlorocyclohexane]

\begin{tabular}{|c|c|c|c|c|}
\hline \multirow{2}{*}{ Compound } & \multirow{2}{*}{$\mathbf{N}$} & \multicolumn{3}{|c|}{ Recovery } \\
\hline & & $\min$ & $\max$ & med \\
\hline \multicolumn{5}{|c|}{ Bed sediment } \\
\hline$[\mathrm{D} 6] \alpha-\mathrm{HCH}$ & 31 & 17 & 81 & 63 \\
\hline 3,5-Dichlorobiphenyl & 31 & 35 & 96 & 55 \\
\hline Octachlorobiphenyl & 30 & 16 & 100 & 61 \\
\hline [D14]Terphenyl & 31 & 32 & 120 & 68 \\
\hline 2-Fluorobiphenyl & 31 & 27 & 86 & 59 \\
\hline [D5]Nitrobenzene & 31 & 32 & 98 & 59 \\
\hline \multicolumn{5}{|c|}{ Tissue } \\
\hline$[\mathrm{D} 6] \alpha-\mathrm{HCH}$ & 6 & 76 & 113 & 100 \\
\hline 3,5-Dichlorobiphenyl & 6 & 52 & 108 & 79 \\
\hline
\end{tabular}

\section{IMPLICATIONS FOR SAMPLING AND DATA ANALYSIS}

The quality control data summarized in this report become relevant only when they are considered in concert with the environmental samples collected in the Western Lake Michigan Drainages study unit. For example, the importance of the detections in the blanks can be determined only by comparison with the environmental samples. In the case of most constituents detected in blanks, the environmental samples will likely have an order of magnitude or higher concentration. In these cases, no correction of environmental data would be warranted. To address the low-level 
detections, however, better attention to cleaning of equipment and storing major ion samples in non-glass bottles would be advised. An exception to this generality is the frequent and high concentration of DOC in several surface and ground-water blanks. Concentrations of DOC in surface and ground-water blanks are likely significant with respect to commonly measured environmental concentrations, and the data will have to be qualified accordingly. Modifications to the cleaning procedure should reduce both the frequency and magnitude of DOC contamination.

The precision of sampling, as determined from replicates and splits, is generally proportional to the concentration of the constituents. That is, constituents that are present in relatively high concentrations generally have less sampling variability on a percent basis. In general, analytes with relatively high variability between replicates were present near the reporting limit or were associated with relatively small absolute concentration differences, or both. Precision among replicates and splits in bed sediment samples was similar, thus eliminating sampling as a major source of variability in analyte concentrations. In the case the phthalates in bed sediment, contamination in either the field or laboratory could have caused the relatively large variability between replicate samples and between split samples. As expected, higher variability was noted for analytes in the more heterogeneous, $<2 \mathrm{~mm}$ fraction compared to that in the $<63 \mu \mathrm{m}$ fraction. Variability of analyte concentrations in tissue samples was relatively low, being 29 percent or less for all constituents.

On the basis of only two field matrix spike sets, recoveries of most schedule 2001/2010 pesticide spike compounds in surface-water samples were reasonably good. Low intrinsic method recovery resulted in rela- tively low recovery for $p, p^{\prime}-\mathrm{DDE}$, metribuzin, and propargite. In the case of propargite, decomposition with the environmental sample matrices was also indicated. Recoveries of two compounds, cyanazine and thiobencarb, might have been biased high due to interferences. More confidence could be placed in these conclusions had more field matrix spike recovery data been available for analysis. The one schedule 2050/2051 field matrix spike indicated numerous operational problems with this method that biased recoveries either low or high.

Recoveries of pesticides from both schedules in field spikes of ground-water samples generally were similar to those of field matrix spikes of surface-water samples. High maximum recoveries were noted for tebuthiuron, disulfoton, DCPA, and permethrin, which indicates the possible presence of interferents in the matrices for these compounds. Recovery problems for pesticides on the 2050/2051 schedule in ground water generally were the same as for surface water. Recoveries of VOCs in field matrix spikes were reasonable when consideration was given for the use of the micropipettor that delivered only about 80 percent on average of the nominal mass of spiked analytes.

Finally, the recoveries of most surrogate compounds in surface and ground-water samples indicated no major analytical problems in those analyses. In general, the occasional low recoveries observed did not correlate with low recoveries observed in field matrix spikes. Therefore, problems in sample handling (for example, spillage) were likely not the cause of any of the low recoveries of spiked compounds although they cannot, of course, be ruled out. 


\section{REFERENCES CITED}

Crawford, J.K., and Luoma, S.N., 1993, Guidelines for studies of contaminants in biological tissues for the National Water-Quality Assessment Program: U.S. Geological Survey Open-File Report 92-494, 69 p.

Foreman, W.T., Connor, B.F., Furlong, E.T., Vaught, D.G., and Merten, L.M., 1995, Methods of analysis by the U.S. Geological Survey National Water Quality Laboratory -- Determination of organochlorine pesticides and polychlorinated biphenyls in bottom sediment by dual capillary-column gas chromatography with electron-capture detection: U.S. Geological Survey OpenFile Report 95-140, 78 p.

Foreman, W.T., and Gates, P.M., 1997, Matrix-enhanced degradation of $p, p$ '-DDT during gas chromatographic analysis: a consideration, Env. Sci. Tech. 31(3) p. 905910.

Furlong, E.T., Vaught, D.G., Merten, L.M., Foreman, W.T., and Gates, P.M., 1996, Methods of analysis by the U.S. Geological Survey National Water Quality Laboratory -- Determination of semivolatile organic compounds in bottom sediment by solvent extraction, gel permeation chromatographic fractionation, and capillary-column gas chromatography/mass spectrometry: U.S. Geological Survey Open-File Report 95-719, 67 p.

Gilliom, R.J., Alley, W.M., and Gurtz, M.E., 1994, Design of the National Water-Quality Assessment Program: Occurrence and distribution assessment: U.S. Geological Survey Open-File Report 94-314, 50 p.
Koterba, M.T., Wilde, F.D., and Lapham, W.W., 1995, Ground-water data-collection protocols and procedures for the National Water-Quality Assessment Program - Collection and documentation of water quality samples and related data: U.S. Geological Survey Open-File Report 95-399, 113 p.

Shelton, L.R., 1994, Field guide for collecting and processing stream-water samples for the National Water-Quality Assessment Program: U.S. Geological Survey Open-File Report 94-455, 42 p.

Shelton, L.R., and Capel, P.D., 1994, Guidelines for collecting and processing samples of stream bed sediment for analysis of trace elements and organic contaminants for the National Water-Quality Assessment Program: U.S. Geological Survey Open-File Report 94-458, 20 p.

U. S. Geological Survey National Water Quality Laboratory Technical Memorandum 92-01 - Technology Transfer Availability of equipment blank water for inorganic and organic analysis.

Zaugg, S.D., Sandstrom, M.W., Smith, S.G., and Fehlberg, K.M., 1995, Methods of analysis by the U.S. Geological Survey National Water Quality Laboratory -- Determination of pesticides in water by $\mathrm{C}-18$ solid-phase extraction and capillary-column gas chromatography/ mass spectrometry with selected-ion monitoring: U.S. Geological Survey Open-File Report 95-181, 60 p. 